\title{
Pembinaan Moral dan Spiritual pada Warga Binaan (Studi Kasus di Lembaga Pemasyarakatan Kelas IIa Pekanbaru)
}

\author{
Try Wiganda $\operatorname{Irfan}^{1}$, Hasrul $^{2}$ dan Isnarmi ${ }^{3}$ \\ 1,2,3 Fakultas Ilmu Sosial, Universitas Negeri Padang, Padang, Indonesia \\ e-mail: ${ }^{1}$ trywigandairfan@gmail.com, ${ }^{2}$ hasrul.unp.fis.ac.id@gmail.com, ${ }^{3}$ aanisnarmi@gmail.com
}

\begin{abstract}
ABSTRAK. Penelitian ini membahas proses pembinaan moral dan spiritual pada warga binaan pemasyarakatan di Lembaga Pemasyarakatan Kelas IIA Pekanbaru.Tujuan penelitianyaitu untuk mengetahui dan menganalisis bentuk pelaksanaan pembinaan moral dan spiritual di Lembaga Pemasyarakatan Kelas IIA Pekanbaru.Penelitian ini mengguakan metode deskriptif dengan pendekatan kualitatif.Teknik pengumpulan data melalui wawancara, dokumentasi dan observasi terhadap pejabat, petugas lembaga pemasyarakatan,dai dan pendeta serta warga binaan. Hasil penelitian menunjukkan bahwa bentukpembinaanmoral dan spiritual pada warga binaan di Lembaga Pemasyarakatan Kelas IIA Pekanbaruyaitu berupa dakwah lisan.
\end{abstract}

ABSTRACT This study discusses the process of moral and spiritual formation of prisoners in the Pekanbaru Class IIA Correctional Institution. The purpose of this study is threefold, namely to know and analyze the form of implementation of moral and spiritual formation in Pekanbaru Class IIA Correctional Institution. This research uses descriptive method with a qualitative approach. The technique of collecting data is through interviews, documentation and observations of officials, prison officials, dai and pastors and assisted citizens. The results showed that the forms of moral and spiritual formation in the assisted citizens of the Class IIA Correctional Institution in Pekanbaru were in the form of oral preaching, preaching writing and action preaching.

Kata Kunci: Moral, Spiritual, Warga Binaan. 


\section{PENDAHULUAN}

Kemerosotan moral yang terjadi pada saat sekarang salah satu penyebabnya yaitu keringnya jiwa manusia dari nilai-nilai spiritual serta jauh dari ajaran agama.Jenis kerusakan yang ditimbulkan di antaranya adalah timbulnya perkelahian, pemerkosaan, pembunuhan, perampokan, penganiayaan, serta penggunaan obat-obatan terlarang (narkoba). Tindak kriminalitas atau kejahatanmemiliki sifat yang merugikan masyarakat yang dilakukan oleh anggota masyarakat juga, pemerintah melalui aparat penegak hukum berusaha menanggulangi gangguan - gangguan dari tindak kejahatan tersebut (Ningtyas, Gani, dan Sukanto 2014). Maka dari itu untuk menampung para pelaku kriminalitas agar tidak meresahkan masyarakat dan supaya mereka tidak mengulangi kesalahannya, pemerintah mendirikan suatu Lembaga Pemasyarakatan (Lapas).

Lembaga Pemasyarakatan merupakan institusi dari sub sistem peradilan pidana mempunyai fungsi strategis sebagai pelaksanaan pidana penjara dan sekaligus tempat pembinaan narapidana sebagaimana diamanatkan Undang - undang No 12 Tahun 1995 tentang Pemasyarakatan (Angkasa 2010). Lembaga Pemasyarakatan Kelas IIA Pekanbaru sebagai Unit Pelaksana Teknis (UPT) yaitu membina warganya dengan meningkatkan bimbingan mental, moral, spiritual, sosial dan tingkat kesadaran hukum serta peningkatan keterampilan kerja sebagai modal atau bekal untuk memperbaiki tingkat kehidupannya kelak kembali ke dalam lingkungan masyarakat.Permasalahan pembinaan warga binaan di lembaga pemasyarakatan yaitu daripembina yang tidak sesuai membina dengan latar belakang warga binaanserta tidaksesuainya metode pembinaan warga binaan(Enggarsasi et al. 1995), kedua dari partisipasi warga binaan yang rendah dan malas - malasan dalam pembinaan(Dwiatmodjo 2013). ketiga kurangnya dana operasional pembinaan(Tjahjati 1968).

Terkait dengan pembinaan spiritual pada warga binaan, sudah banyak penelitian yang telah dilakukan, artikel berjudul "Pembinaan Moral Keagamaan Narapidana di Lembaga Pemasyarakatan". Di dalam artikel ini menceritakan tentangLembaga Pemasyarakatan dan dakwah Islam yang memiliki kesamaan peran yaitu sama-sama berfungsi sebagai pembinaan moral keagamaan bertujuan membentuk manusia seutuhnya serta untuk mengembalikan fitrah kemanusiaan agar bisa bersosialisasi dengan masyarakat(D. I. L. Pemasyarakatan 2015). Artikel ini berkaitan dengan apa yang diteliti dalam penelitian saya karena juga membahas fungsi pembinaan spiritual pada warga binaan di Lembaga Pemasyarakatan Kelas IIA Pekanbaru.

Selanjutnya dalam peneltian dengan berjudul "Metode Pembinaan Keagamaan yang Efektif Bagi Narapidana/Tahanan di Lembaga Pemasyarakatan Kelas II-B Lumajang”Penelitian ini bertujuan untuk mencoba tiga metode keagamaan di Lembaga Pemasyarakatan Kelas II-B Lumajang(L. Pemasyarakatan dan Lumajang n.d.). Selanjutnya penelitian dengan berjudul "Pendidikan Akhlak Pada Napi Anak Di Lapas Kelas IIA Curup" penelitian ini bertujuan menganalisi tentang Pendidikan Agama Islam Pada Anak Yang Berhadapan Dengan Hukum (ABH) di Lapas Klas IIA Curup(Islam dan Curup 2017).Kemudian penelitiandengan berjudul "Pemenuhan Hak-Hak Pendidikan Keagamaan Islam Anak Binaan di Lembaga Pemasyarakatan Pakjo Palembang" penelitian ini bertujuan bagaimana pendidikan Keagamaan Islam Anak Binaan di Lembaga Pemasyarakatan Pakjo Palembang(Di, Pemasyarakatan, dan Palembang n.d.).

Selanjutnya penelitian dengan berjudul "Peranan Bimbingan Konseling Islam dalam Meningkatkan Moral Narapidana Anak: Studi Pada Bapas Kelas I Semarang" tulisan ini bertujuan mendeskripsikan tentang bagaimana peran BAPAS KelasI Semarang dalam membimbing dan konseling Islam dalam meningkatkan moralitas narapidana anak(Khasanah dan Umriana 2017). Selanjutnya penelitian dengan berjudul "Pembinaan Mental Narapidanadi Lembaga Pemasyarakatan Wirogunan Yogyakarta" tujuan penelitian ini untuk mengetahui realitas pelaksanaan pembinaan mental, hambatan-hambatan serta upaya mengatasihambatan tersebut(Astuti 2011).

Selanjutnya penelitian dengan berjudul "Pembinaan Keagamaan Pada Narapidana Anak (Studi Deskriptif Pada Lembaga Pemasyarakatan Anak Kelas III Bandung)" penelitian ini 
bertujuan untuk mengetahui perencanaan, pelaksanaan serta hasil dari program pembinaan keagamaan di lapas anak Bandung(Bandung 2015).Artikel ini juga berkaitan dengan penelitian yang saya lakukan karena masih membahasa bentuk pelaksanaan, mengetahui kendala serta solusi dari pembinaan di Lembaga pemasyarakatan Kelas IIA Pekanbaru.Secara umum ide-ide dari penelitian terdahulu ini sangat relevan dengan artikel ini yang sama-sama untuk mengetahui dan menganalisis bentuk pelaksanaanpembinaan dan upaya serta mengungkap faktor pendukung dan penghambat pembinaan serta solusinya. Namun pada penelitian terdahulu lebih menonjolkan kepada aspek program pembinaan, sedangkan artikel ini lebih spesifik terhadap warga binaan dan dainya.

\section{Metode}

Penelitian ini menggunakanmetode deskriptif kualitatif. Studi deskriptif adalah mengungkapkan kejadian atau fakta, keadaan, fenomena, variabel dan keadaan yang terjadi saat penelitian berlangsung dengan menyuguhkan apa yang sebenarnya terjadi(Sugiyono 2011).Dengan demikian,pengumpulan data dalam penelitian ini dilakukan dengan menggunakan beberapa cara yaituobservasi, wawancara dan dokumentasiterhadap pejabat lembaga pemasyarakatan,dai yang memberikan ceramah serta warga binaan.

\section{Hasil dan Pembahasan}

Pelaksanaan pembinaan spiritual di Lembaga Pemasyarakatan Klas IIA Pekanbaru, berdasarkan hasil observasi, wawancara dan dokumentasi yang dilakukan terdapatsatu bentuk pembinaan yakni dakwah lisan. Bentuk pelaksanaan pembinaan tersebut dapat dilihat dalam skema berikut:

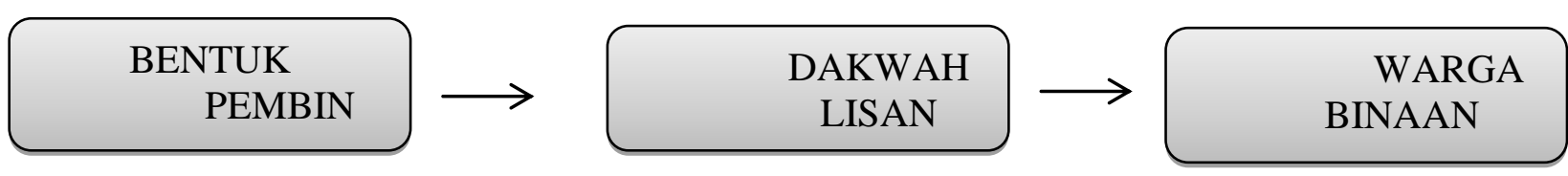

\section{Gambar 1. Skema Bentuk Pembinaan di Lembaga Pemasyarakatan Klas IIA Pekanbaru}

\section{Dakwah Lisan di Lembaga Pemasyarakatan Kelas IIA Pekanbaru}

Berdasarkan Permen No6 Tahun 2013 tentang tata tertib lembaga pemasyarakatan dan rumah tahanan pasal 3 bahwa setiap narapidana wajib mengikut seluruh kegiatan yang diprogramkan oleh pihak lembaga pemasyarakatan. Program pembinaan kepribadian yang diprogramkan oleh pihak Lembaga Pemasyarakatan Kelas IIA Pekanbaru seperti ceramah, sholat dan baca tulis al qur'an. Adapun yang dijelaskan yaitu ceramah yaitu sebagai berikut :

\section{Ceramah}

Ceramah merupakan salah satu kegiatan yang tertulis di SOP pelaksanaan pembinaan kepribadian berdasarkan dengan Kep.Dirjen Pemasyarakatan Tahun 2013 tentang Pedoman Pembinaan Kepribadian Narapidana. Ceramah merupakan proses penyampaian ajaran agama, baik yang bersifat larangan maupun yang bersifat perintah dan anjuran kepada warga binaan sebagai obyek dakwah dengan menggunakan lisan sebagai alat.

Peneliti melihat proses pembinaan moral dan spiritual agama Islam yang rutin selalu dilaksanakan setiap hari senin sampai dengan sabtu yaitu dengan ceramah. Warga binaan selalu dihimbau setiap hari senin sampai dengan sabtu oleh pihak lembaga pemasyarakatan untuk mengikuti pembinaan kepribadian. Kemudian warga binaan yang ikut hadir dalam pembinaan kepribadian tersebut mengisi absensi yang telah disediakan oleh pihak lembaga pemasyarakatan. Proses selanjutnya dai memberikan ceramah agama kepada warga binaan yang berlangsung 125 
menit di mesjid at - taubah. Adapun yang dijelaskan dalam ceramah yaitu dai, materi, metode, media, jadwal kegiatan dan dana operasional yaitu sebagai berikut :

\section{Dai}

Dai merupakan orang yang melakukan dakwah, atau dapat diartikan sebagai orang yang menyampaikan pesan dakwah kepada warga binaan. Peneliti melihat dai yang memberikan pembinaan moral dan spiritual di Lembaga Pemasyarakatan Kelas IIA Pekanbaru berasal dari berbagai lembaga dakwah yang ada di kota pekanbaru. Berdasarkan PP No 57 Tahun 1999 tentang kerjasama penyelenggaraan pembinaan dan pembimbingan warga binaan pemasyarakatan bahwa pihak lembaga pemasyarakatan wajib menjalin kerjasama dengan lembaga swadaya masyarakat atau badan - badan kemasyarakatan dalam pembinaan kepribadian.

Peneliti mendapatkan data dari pihak Lembaga Pemasyarakatan Kelas IIA Pekanbaru bahwa telah menjalin kerjasama dengan lembaga dakwah di Provinsi Riau seperti Majelis Dakwah Islamiyah, Ikatan Mesjid Indonesia, dan Jamaah Tabligh dalam membina warga binaan. Majelis Dakwah Islamiyah dan Ikatan Mesjid Indonesia merupakan organisasi yang bergerak dibidang dakwah Islam di Kota Pekanbaru Provinsi Riau. Kerjasama yang dilakukan berupa tenaga pengajar untuk membina warga binaan.

Adapun asal lembaga dakwah para dai yang menyampaikan ceramah di Lembaga Pemasyarakatan Kelas IIA Pekanbaru, maka dapat dilihat pada tabel berikut :

\begin{tabular}{cc}
\hline Nama Dai & Lembaga Dakwah \\
\hline UST. Drs. Harromaini & Majelis Dakwah Islamiyah \\
\hline UST. Mirwan, M.Pdi & Majelis Dakwah Islamiyah \\
\hline BUYA MAKMUR & Majelis Dakwah Islamiyah \\
\hline UST. Drs. Wizard Adnan & Ikatan Mesjid Indonesia \\
\hline UST. Safrullah & Jamaah Tabligh \\
\hline Tabel 3 Dai Berdasarkan Asal Lembaga Dakwah
\end{tabular}

Kemudian dai tentu harus mempunyai kompetensi yang baik untuk membina warga binaan di Lembaga Pemasyarakatan Kelas IIA Pekanbaru. Keilmuan yang mempuni juga menjadi salah satu faktor keberhasilan dalam pembinaan moral dan spiritual, maka dapat dilihat pada tabel berikut :

\begin{tabular}{ccc}
\hline No & Nama Dai & Tingkat Pendidikan \\
\hline $\mathbf{1}$ & UST. Drs. Harromaini & S1 \\
\hline $\mathbf{2}$ & UST. Mirwan, M.Pdi & S2 \\
\hline $\mathbf{3}$ & BUYA MAKMUR & SMA \\
\hline $\mathbf{4}$ & UST. Drs. Wizard Adnan & S1 \\
\hline $\mathbf{5}$ & UST. Safrullah & S1 \\
\hline
\end{tabular}

Tabel 2 Dai Berdasarkan Tingkat Pendidikan

\section{Materi Ceramah}

Peneliti melihat, mendengarkan dan mewawancarai para dai mengenai materi ceramah yang disampaikan. Bahwa materi ceramah bersumber pada Al - Qur'an yang merupakan sumber petunjuk sebagai landasan Islam, karena itu sebagai materi utama dalam berdakwah. Kemudian As - Sunnah (Hadis) merupakan sumber kedua dalam Islam. Hadis merupakan penjelasan penjelasan dari Nabi dalam merealisasikan kehidupan berdasar Al - Qur'an. Dengan menguasai $\mathrm{Al}$ - qur'an dan hadis maka seorang dai telah memiliki bekal dalam menyampaikan tugas dakwah. Materi ceramah yang disampaikan para dai kepada warga binaan di Lembaga Pemasyarakatan Kelas IIA Pekanbaru. Maka dapat dilihat pada tabel berikut :

\begin{tabular}{lll}
\hline No & Nama Dai & Materi Agama Islam \\
\hline
\end{tabular}




\begin{tabular}{ccc}
\hline $\mathbf{1}$ & UST. Drs. Harromaini & Aqidah Akhlak \\
\hline $\mathbf{3}$ & UST. Ali Imron, S.Pdi & Aqidah Akhlak \\
\hline $\mathbf{4}$ & UST. Mirwan, M.Pdi & Alquran Hadist \\
\hline $\mathbf{5}$ & BUYA MAKMUR & Kajian Tasawuf \\
\hline $\mathbf{6}$ & UST. Drs. Wizard Adnan & Ilmu Fiqih \\
\hline $\mathbf{7}$ & UST. Safrullah & Fadilah Amal \\
\hline
\end{tabular}

Tabel 4 Materi Ceramah Lembaga Pemasyarakatan Kelas IIA Pekanbaru

Adapun pokok pembahasan materi ceramah agama Islam di Lembaga Pemasyarakatan Kelas IIA Pekanbaru, maka dapat dilihat pada tabel sebagai berikut :

\begin{tabular}{|c|c|c|}
\hline No & Materi & Pokok Pembahasan \\
\hline 1 & AqidahAkhlak & $\begin{array}{l}\text { Aqidah yaitu: iman kepada Allah SWT, iman } \\
\text { kepada malaikat- malaikat Allah, iman kepada } \\
\text { kitab- kitab Allah, iman kepada Nabi dan Rasul, } \\
\text { iman kepada hari akhir, iman kepada qadha dan } \\
\text { qadar Allah. } \\
\text { Akhlak yaitu: akhlak terhadap Allah SWT, } \\
\text { akhlak terhadap Manusia dan akhlak terhadap } \\
\text { Alam. }\end{array}$ \\
\hline 2 & 1 - qur'an Hadist & $\begin{array}{l}\text { Membaca Al- Qur'an dengan penerapan ilmu } \\
\text { tajwid dan belajar seni tilawah Al - Qur'an. } \\
\text { Mempelajari Hadits - hadist tentang amal } \\
\text { shalih, thaharah, shalat, dzikir, puasa, dan } \\
\text { haji/umrah. }\end{array}$ \\
\hline 3 & ᄃajian Tasawuf & I sifat - sifat Allah SWT. \\
\hline 4 & Ilmu Fiqih & $\begin{array}{l}\text { Islam, Iman, Ikhsan, Tharah, Shalat, dan } \\
\text { Shalawat Kepada Nabi Saw. }\end{array}$ \\
\hline & Fadilah Amal & $\begin{array}{l}\text { Kisah - kisah Sahabat, Fadhilah Shalat, } \\
\text { Fadhilah Dzikir, Fadhilah Ramadhan, dan } \\
\text { Fadhilah Al - Qur'an. }\end{array}$ \\
\hline
\end{tabular}

Tabel 5Pokok Pembahasan Materi Ceramah Lembaga Pemasyarakatan Kelas IIA Pekanbaru

Berdasarkan temuan di lapangan bahwa materi yang disajikan sangat diperlukan oleh warga binaan untuk menjadi warga binaan yang taat hukum dan taat beribadah. Kemudian kesemua materi tersebut sudah mencakup dan seimbang materi syariah, akhlak dan akidah.

\section{Metode Ceramah}

Metode berarti cara yang diatur dan melalui proses pemikiran untuk mencapai suatu maksud. Kemudian metode ceramah merupakan cara penyampaian para dai kepada warga binaan tentang materi ceramah, maka dapat dilihat pada tabel berikut:

\begin{tabular}{cc}
\hline No & Metode Ceramah \\
\hline $\mathbf{1}$ & $\mathrm{Al}-$ Hikmah \\
\hline $\mathbf{2}$ & $\mathrm{Al}-$ Mau'idza Al - Hasanah \\
\hline $\mathbf{3}$ & $\mathrm{Al}$ Mujadalah \\
\hline
\end{tabular}

Tabel 6 Metode Ceramah di Lembaga Pemasyarakatan Kelas IIA Pekanbaru

\section{1) Media Ceramah}

Media ialah alat atau wahana yang digunakan untuk memindahkan pesan dari sumber kepada penerima. Untuk itu berkomunikasi bermedia adalah komunikasi yang menggunakan saluran atau sarana untuk meneruskan suatu pesan kepada komunikan 
yang jauh tempatnya dan atau banyak jumlahnya. Kemudian mediaceramah yang digunakan oleh para dai untuk menyampaikan materi ceramah kepada para warga binaan di Lembaga Pemasyarakatan Kelas IIA Pekanbaru, maka dapat dilihat pada tabel berikut:

\begin{tabular}{cc}
\hline No & Media Ceramah \\
\hline $\mathbf{1}$ & Microphone \\
\hline $\mathbf{2}$ & Mimbar \\
\hline $\mathbf{3}$ & Papan Tulis \\
\hline
\end{tabular}

Tabel 5 Media Ceramah di Lembaga Pemasyarakatan Kelas IIA Pekanbaru

\section{Jadwal Kegiatan}

Peneliti melihat sebuah proses pembinaan moral dan spiritual di Lembaga Pemasyarakatan Kelas IIA Pekanbaru sudah terjadwal dan terstruktur. Terlihat dari kegiatan - kegiatan keagamaan yang sudah di program dengan baik seperti dai, materi dan waktu pembinaannya. Kegiatan ceramah yang dilaksanakan setiap hari senin sampai sabtu di mesjid at - taubah mulai pukul 11:30 wib - 12:00 wib. Untuk lebih jelas dapat dilihat berdasarkan tabel berikut :

\begin{tabular}{cccc}
\hline No & HARI & PUKUL & KEGIATAN \\
\hline $\mathbf{1}$ & SENIN & $11: 30 \mathrm{WIB}-$ & Kajian Akidah \\
& & $12: 00 \mathrm{WIB}$ & Akhlak \\
\hline $\mathbf{2}$ & SELASA & $11: 30 \mathrm{WIB}-$ & Kajian Fadilah \\
& & $12: 00 \mathrm{WIB}$ & Amal \\
\hline $\mathbf{3}$ & RABU & $11: 30 \mathrm{WIB}-$ & Kajian Al Qur'an \\
& & $12: 00 \mathrm{WIB}$ & Hadist \\
\hline $\mathbf{4}$ & KAMIS & $11: 30 \mathrm{WIB}-$ & Kajian Ilmu Fiqih \\
& & $12: 00 \mathrm{WIB}$ & \\
\hline $\mathbf{5}$ & SABTU & $11: 30 \mathrm{WIB}-$ & Kajian Ilmu \\
& & $12: 00 \mathrm{WIB}$ & Tasawuf \\
\hline
\end{tabular}

Tabel 6 Kegiatan Rutin Santri Mesjid At -Taubah Lapas Kelas IIA Pekanbaru

\section{Dana Operasional Ceramah}

Dalam melaksanakan kegiatan ceramah di Lembaga Pemasyarakatan Kelas IIA Pekanbaru diperlukan sebuah dana operasional. Peneliti menemukan sebuah temuan dilapangan bahwa terdapat kekurangan dana operasional kegiatan ceramah di Lembaga Pemasyarakatan Kelas IIA Pekanbaru terlihat dari dihimbau para warga binaan untuk berinfak setiap kegiatan berlangsung bertujuan untuk membayar para dai serta untuk dana tabungan kegiatan pembinaan agama. Maka dapat disimpulkan bahwa terdapat kekurangan dana operasional dalam melaksanakan ceramah di Lembaga Pemasyarakatan Kelas IIA Pekanbaru.

Berdasarkan penjelasan diatas bahwa pembinaan moral dan spiritual telah dilaksanakan oleh pihak Lembaga Pemasyarakatan Kelas IIA Pekanbaru yang bertujuan untukmenjadikan warga binaanyangbermoral, taat beribadah dan taat hukum dalam kehidupan di bernegara.

\section{Simpulan}

Penelitian yang dilakukan dengan mengunakan metode triangulasi data yaitu berawal dari observasi wawancara mendalam, dan dokumentasi. Berdasarkan penelitian yang telah dilakukan dapat diambil kesimpulan, antara lain: 
1. Implementasi dari pembinaan moral pada warga binaan pemasyarakatan di Lembaga Pemasyarakatan Kelas IIA Pekanbaru berkaitan dengan pemberian pengalaman untuk membentuk kepribadian warga binaan menjadi lebih baik supaya dapat menghadapi kondisi masyarakat ketika keluar kelak. Hasil dari pembinaan moral tersebut menghasilkan kepribadian warga binaan pemasyarakatan yang sesuai dengan prinsip - prinsip moral dasar yaitu sikap baik, keadilan, dan hormat terhadap diri sendiri.

2. Implementasi dari pembinaan spiritual pada warga binaan pemasyarakatan di Lembaga Pemasyarakatan Kelas IIA Pekanbaruberkaitan dengan pemberian arahan tentang kerohanian yang bertujuan untuk memberikan pengetahuan ilmu keagamaan supaya dapat menambah keimanan dan ketaqwaan. Implementasi dari pembinaan spiritual terlihat dari kegiatan rohani yang dilaksanakan rutin setiap hari senin sampai hari sabtu.

3. Implementasi pembinaan moral dan spiritual di Lembaga Pemasyarakatan Kelas IIA Pekanbaru terdapat kendala yaitu dari warga binaan itu sendiri yang tidak mengikuti kegiatan pembinaan dengan acuh tak acuh dan bahkan cenderung mengabaikannya, kurang koordinasi dan kerjasama antara dai denga pihak lembaga pemasyarakatan serta dana operasional pembinaan.

\section{Referensi}

\section{Jurnal :}

Angkasa. (2010). Over capacity narapidana di lembaga pemasyarakatan, faktor penyebab, implikasi negatif, serta solusi. Jurnal Dinamika Hukum. 10(3): 213-21.

Astuti, Ari. (2011). Pembinaan mental narapidana di Lembaga Pemasyarakatan Wirogunan Yogyakarta. Jurnal Citizenship. 1(1): 29-45.

Enggarsasi, Umi I I I. (1995). Pola Pembinaan Narapidana. 2: 16-24.

Di, Binaan, Lembaga Pemasyarakatan, dan Pakjo Palembang. "PEMENUHAN HAK-HAK PENDIDIKAN KEAGAMAAN ISLAM ANAK BINAAN DI LEMBAGA PEMASYARAKATAN PAKJO PALEMBANG Abstrak."

Dwiatmodjo, Haryanto. 2013. "Pelaksanaan pidana dan pembinaan narapidana tindak pidana narkotika (Studi terhadap pembinaan narapidana di Lembaga Pemasyarakatan narkotika klas IIA Yogyakarta).” Perspektif 18(2): 64-73.

Enggarsasi, Umi et al. 1995. "Pola Pembinaan Narapidana." : 157-68.

Islam, Jurnal Pendidikan, dan Stain Curup. 2017. "No Title.” 2(02).

Khasanah, Yuli Nur, dan Anila Umriana. 2017. "PERANAN BIMBINGAN KONSELING ISLAM DALAM MENINGKATKAN MORAL NARAPIDANA ANAK: Studi pada BAPAS Kelas I Semarang." 12(April): 207-24.

Ningtyas, Erina Suhestia, Abd. Yuli Andi Gani, dan Sukanto. 2014. "Pelaksanaan Program Pembinaan Narapidana Pada Lembaga Pemasyarakatan Dalam Rangka Pengembangan Sumber Daya Manusia." Administrasi Publik 1(6): 1266-75.

Pemasyarakatan, D I Lembaga. 2015. "PEMBINAAN MORAL KEAGAMAAN NARAPIDANA." 2(1): 23-42.

Pemasyarakatan, Lembaga, dan Kelas Ii-b Lumajang. "No Title."

Sugiyono. 2011. "Metode Penelitian Kuantitatif, kualitatif dan R \& D." Bandung: Alfabeta.

Tjahjati, Erna. 1968. "Perlindungan Dan Pembinaan Terhadap Warga Binaan Pemasyarakatan ( Wbp ) ( Study Di Lembaga Pemasyarakatan Anak Klas Iia Blitar ).” : 55-62. 